\title{
Stromal Cells, Macrophages and Lymphoid Cells in the Head-kidney of Sea Bass (Dicentrarchus labrax L.).
} An Ultrastructural Study

\author{
J. Meseguer, M. A. Esteban and B. Agulleiro \\ Department of Cell Biology, Faculty of Biology, University of Murcia, Murcia, Spain
}

Received January 14, 1991

Summary. The ultrastructure of the stromal cells, macrophages and lymphoid cells in the head-kidney of the sea bass (Dicentrarchus labrax L.) was studied. Like mammals, stroma cell types here include endothelial and adventitial cells comprising the sinusoidal wall, fibroblast-like reticular cells related to scarce reticular fibres, and macrophage-type reticulum cells, the last probably corresponding to the resident macrophage population of higher vertebrates. Their possible role in the haemopoietic microenvironment is considered. Monocyte-macrophages, macrophages and melano-macrophages, probably corresponding to ontogenic or functional stages of the same cell type were identified and their functional significances are discussed. Scarce, free lymphoid cells or small clusters of lymphocytes but no lymphopoietic islets were recognizable. Large lymphocytes, small lymphocytes and very scarce developing and mature plasma cells were identified. The lymphoid function and defensive role of the head-kidney were analyzed.

It has been suggested that the haemopoietic stroma of vertebrates plays an essential role in regulating such events as the self renewal, cell interactions and commitment, and differentiation of pluripotential stem cells (CROCKER et al., 1988; OWEN, 1988). The head-kidney represents the main blood-forming organ in teleosts (SMith et al., 1970; BiELEK, 1981) and the major source of blast cells (FÄNGE, 1982). However, only a few references on the presence of a reticular supportive network are available (KANESADA, 1956; SMITH et al., 1970; ZAPATA, 1983), with no data existing on the ultrastructure or functional abilities of the head-kidney stroma cells.

In the haemopoietic tissue of higher vertebrates, several authors have reported a resident macrophage population that is distinct from the immature members of the mononuclear phagocyte system. These cells may play an important role in erythroid homeostasis and provide a range of trophic interactions (Hume et al., 1984; Crocker et al., 1988). The fish head-kidney is considered the main macrophageproducing tissue (BRAUN-NESJE et al., 1981), and the presence of several types of macrophages, probably forming part of the same cell lineage, has been confirmed (ElLIS, 1976; BRAUN-NESJE et al., 1982; Hightower et al., 1984). The macrophage ultrastructure has not been completely established, nor has the presence of a resident macrophage population comparable to those in mammals been reported.

Since early works suggested that the major source of antibody-producing cells in fish was the pronephros (CHILler et al., 1969; SMITH et al., 1970), the structure and function of the lymphoid tissue in the teleost head-kidney have remained poorly understood and the results are sometimes contradictory.

The present study applied ultrastructural criteria to identify and describe the different types of stromal cells, macrophages and lymphoid cells present in the head-kidney of sea bass (Dicentrarchus labrax L.). The results and discussion presented in this paper will provide data for better understanding the haemopoietic system of vertebrates.

\section{MATERIALS AND METHODS}

Twelve specimens of sea bass (Dicentrarchus labrax L.) (about $150 \mathrm{~g}$ in body weight and $20-30 \mathrm{~cm}$ in length) were obtained during spring and winter from 
the Experimental Station of Fish-Farming, San Pedro del Pinatar, Murcia, Spain. They were kept in running seawater aquaria at $17^{\circ} \mathrm{C}$ with a natural photoperiod. The specimens were anaesthetized with MS222 (Sandoz).

\section{Transmission electron microscopy}

Samples of the head-kidney were fixed in $4 \%$ glutaraldehyde in $0.1 \mathrm{M}$ cacodylate buffer, $\mathrm{pH}$ 7.2-7.4, for $5 \mathrm{~h}$ at $4^{\circ} \mathrm{C}$, postfixed in $1 \% \mathrm{OsO}_{4}$ and embedded in Epon. Sections were obtained with a Reichert Jung Ultramicrotome, stained with uranyl acetate and lead citrate, and examined with a Zeiss EM 10C electron microscope.

\section{Scanning electron microscopy}

Samples of the head-kidney were fixed by immersion in $2 \%$ glutaraldehyde in $0.1 \mathrm{M}$ cacodylate buffer, $\mathrm{pH}$ 7.2-7.4 for $2 \mathrm{~h}$ at room temperature, washed in cacodylate buffer, dehydrated in acetone, critical point-dried, sputter-coated with gold and studied with a Jeol JSM T-300 scanning electron microscope.

\section{RESULTS}

\section{Transmission Electron Microscopy}

The sea bass head-kidney consisted of a reticular network of stromal cells, free macrophages and lymphoid elements, besides the erythropoietic, thrombopoietic and granulopoietic cells that we have previously studied (EsTEBAN et al., 1989; MESEGUER et al., 1990).

\section{Stromal cells}

The stromal cell types of the sea bass head-kidney included sinusoidal cells, fibroblast-like reticular cells related to reticular fibres and macrophage-type reticulum cells.

Sinusoidal cells (Fig. 1) formed the barrier between haemopoietic tissue and blood. They included both endothelial and adventitial cells. The endothelial cells were flat and interconnected by cell interdigitations and intercellular junctions. Their cytoplasm contained many small vesicles. Microfilaments, microtubules, a small Golgi apparatus, free ribosomes, lysosomes, peroxisomes and glycogen were also present. A basement membrane was sometimes recognizable. Adventitial cells normally covered most of the outer aspect of the endothelium. Their irregular processes, which formed a perivascular network, were joined by desmosomes, and their cytoplasm contained rare organelles, some filaments and vesicles.

Fibroblast-like reticular cells (Fig. 2) were irregularly branched and formed an extensive network through the haemopoietic tissue. Their large cell processes contained filament bundles and their ends were joined by desmosomes. The cell body contained a round, heterochromatinic nucleus, some mitochondria, free ribosomes, a Golgi apparatus and numerous small light vesicles. The cytoplasm was characterized by the presence of some large, round vesicles which were variable in shape and size and contained a moderatly dense, homogeneous or granular material.

Macrophage-type reticulum cells (Fig. 3) were regularly associated with haemopoietic cells; their cell processes surrounded erythroblasts or other haemopoietic cell types. They possessed a lobed heterochromatinic nucleus and showed numerous vesicles containing a heterogeneous material.

\section{Macrophages}

Monocyte-macrophages, macrophages and melanomacrophages, probably corresponding to different ontogenic or functional stages of the same cell type, were identified.

Monocyte-macrophages (Fig. 4a) were characterized by their eccentric, slightly indented or kidney-shaped nucleus with peripheral heterochromatin and occasional nucleolus as well as by numerous lysosomes of variable size and density. Large mitochondria with

Fig. 1. Endothelial $(E c)$ and adventitial $(A c)$ cells of a sinusoidal wall of the sea bass head-kidney. Sl sinusoidal lumen, arrows cell junctions. $\times 6,500$. Inset: Adventitial cell processes $(A c p)$ covering the outside surface of an endothelial cell $(E c)$. bm Basement membrane. $\times 7,500$

Fig. 2. Fibroblast-like reticular cell. The cytoplasm contains numerous small light vesicles (arrow) and some large vesicles containing a granular material $(L v)$. Erc erythroid cell. $\times 12,500$

Fig. 3. Macrophage-type reticulum cell $(M r c)$ enclosing various haemopoietic cells $(H c)$. The cytoplasm shows numerous vesicles. $C p$ cell processes. $\times 6,500$

Fig. 4 a. Monocyte-macrophage of the sea bass head-kidney. $\times 10,000$. b. Mature activated macrophage containing large phagolysosomes. $\times 6,000$. c. Melano-macrophage. The lysosomes contain haemosiderin $(H s)$ and melanin granules $(\mathrm{Mg}) . \times 12,500$ 



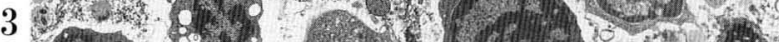

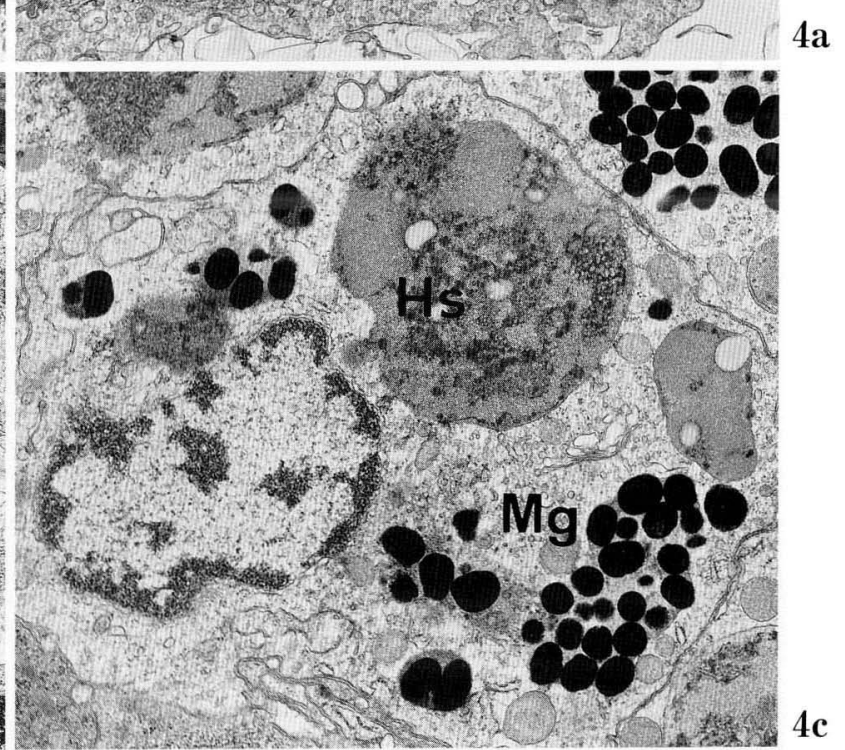

Figs. 1-4. Legends on the opposite page. 


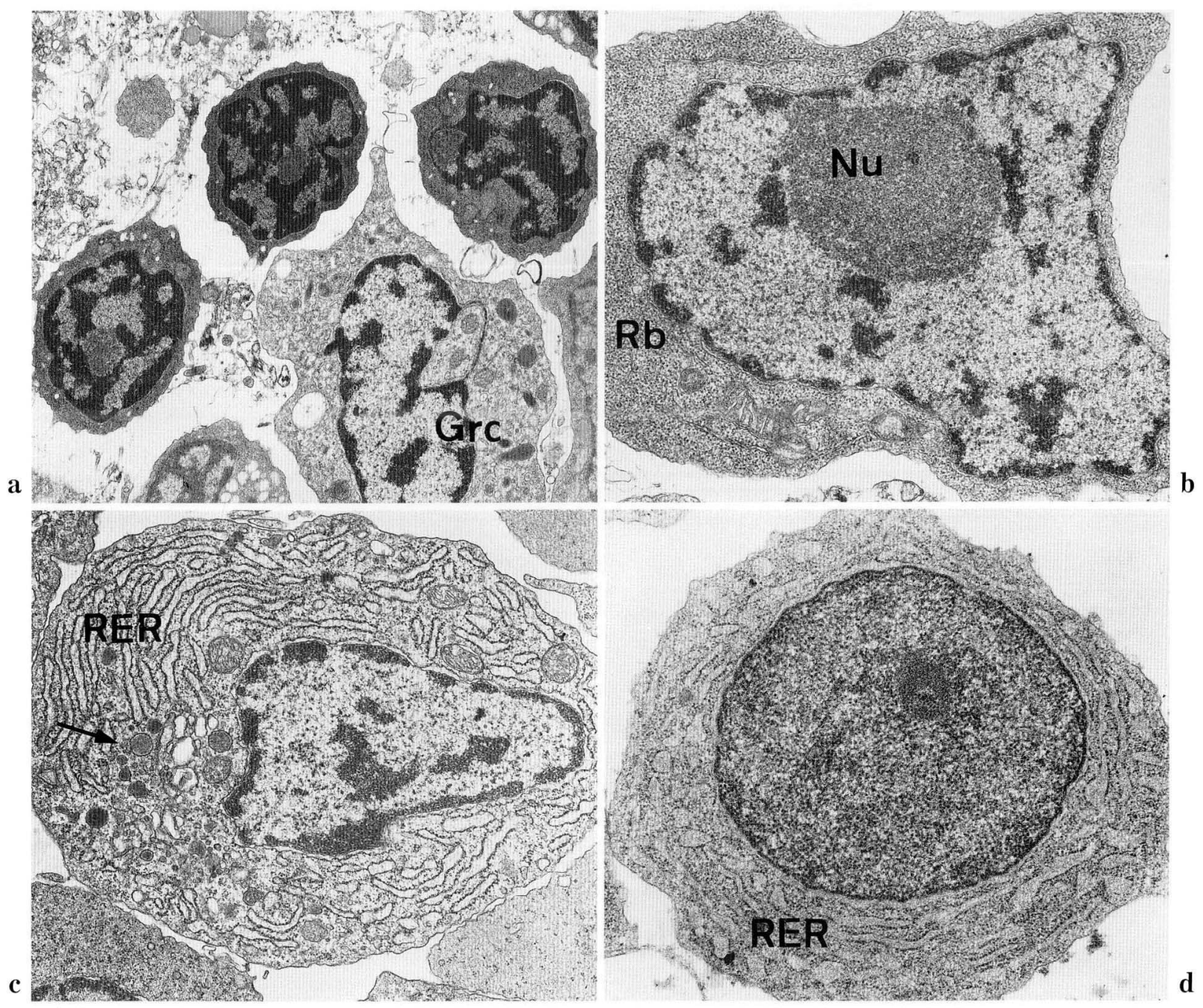

Fig. 5 a. Free lymphoid cells of the sea bass head-kidney. Grc granular cell. $\times 7,500$. b. Large lymphocyte with an euchromatinic nucleus and a prominent nucleolus $(N u)$. $R b$ ribosomes. $\times 12,000$. c. Developing plasma cell. In the cytoplasm, the presence of flattened cisternae, stacks of rough endoplasmic reticulum (RER), and numerous granules $($ arrow) can be noted. $\times 12,500$. d. Mature plasma cell. RER rough endoplasmic reticulum. $\times 11,000$

Fig. 6. Scanning electron micrograph of the reticular network of the sea bass head-kidney. $\times 2,000$

Fig. 7. Scanning electron micrograph of fibroblast-like reticular cells $(F r c)$ showing irregular cytoplasmic processes related to different haemopoietic cells. $\times 3,000$

Fig. 8. Scanning electron micrograph of a macrophage-type reticulum cell showing cell processes involved in the reticular network. $\times 2,000$

Fig. 9. Scanning electron micrograph of a macrophage. The cell surface shows numerous folds or finger-like processes. $\times 3,500$

Fig. 10 a. Scanning electron micrograph of free lymphoid cells $(L c)$. Erc erythroid cell. $\times 2,500$. b. Detail of two lymphocytes $(L)$ showing a rugged cell surface. Erc erythroid cell. $\times 4,500$ 


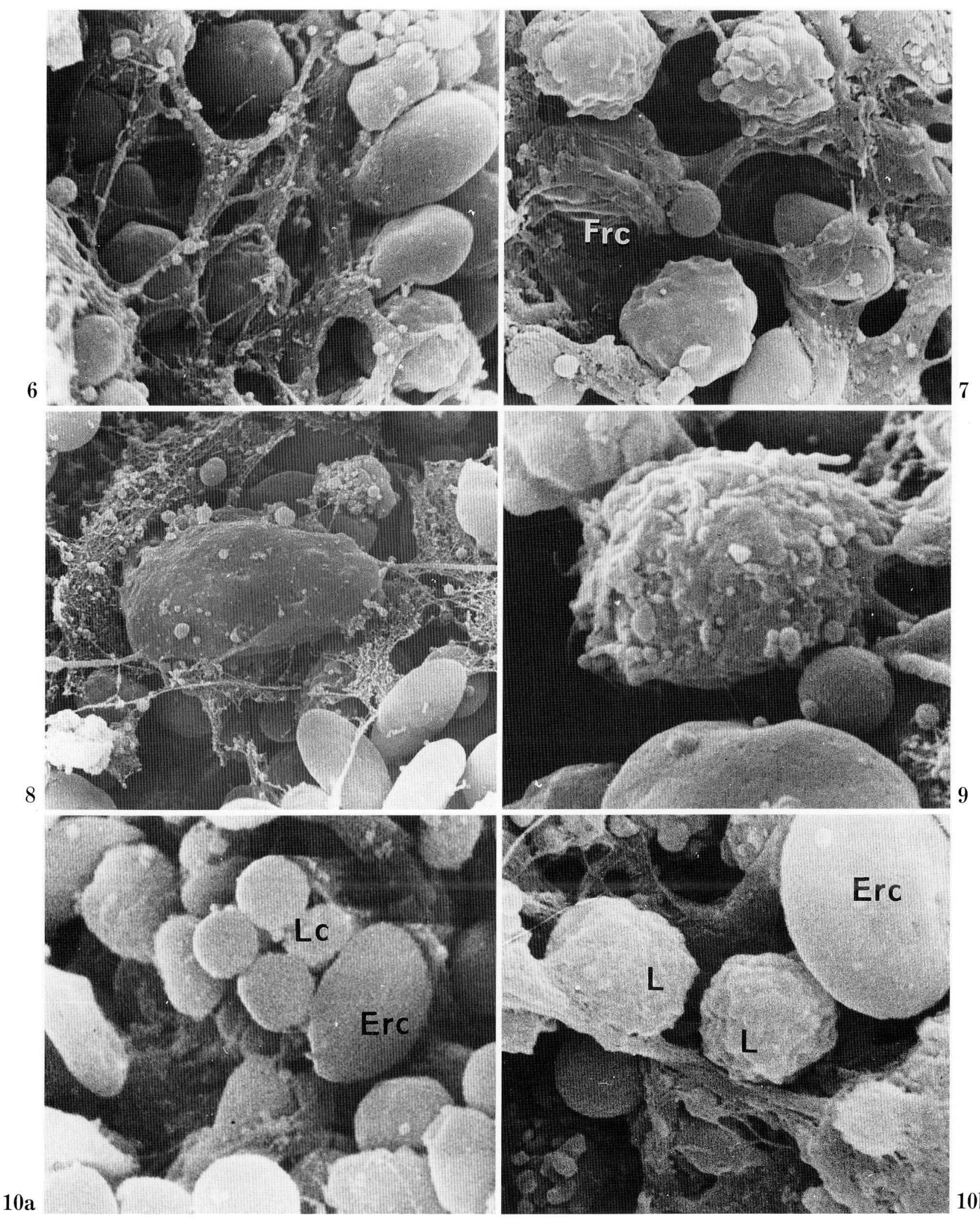

Figs. 6-10. Legends on the oppsite page. 
scarce cristae, a small Golgi apparatus, free ribosomes and some flattened profiles of rough endoplasmic reticulum were also present.

Macrophages (Fig. 4b) shared many ultrastructural features with monocyte-macrophages. Macrophages were large, irregularly shaped cells with an eccentric, irregularly outlined nucleus. Their cytoplasm displayed a heterogeneous appearance because of the occurrence of endocytic vesicles, lysosomes, multivesicular bodies and phagolysosomes. The activated macrophages showed irregular cell processes and numerous phagosomes and lysosomes, some of them containing cell debris.

Melano-macrophages (Fig. 4c) were characterized as free cells or cells clustered in melano-macrophage centres. Both types contained either melanin granules or haemosiderin, both of which were frequently seen together in the lysosomes.

\section{Lymphoid cells}

Free lymphoid cells or small clusters of lymphocytes but no lymphopoietic islets were found (Fig. 5a). Small and large lymphocytes and developing and mature plasma cells were identified.

Small lymphocytes (Fig. 5a) showed a large, oval to round, centrally located nucleus with abundant condensed chromatin and an eccentric nucleolus. The narrow and dense rim of cytoplasm showed one or two large mitochondria and numerous free ribosomes.

Large lymphocytes (Fig. 5b) were round, irregularly outlined cells. Their large, central dense nucleus showed some heterochromatin blocks and a prominent eccentric nucleolus. The rim of cytoplasm had a granular appearance due to the abundance of free ribosomes. It contained only a few mitochondria, some rough endoplasmic reticulum cisternae, and a small Golgi apparatus. Some small peripheral vesicles were also seen.

Developing and mature plasma cells (Fig. 5c, d) were round or ovoid and contained a large, central or eccentric nucleus with peripheral heterochromatin blocks. The most remarkable cytoplasmic feature was the numerous flattened cisternae of rough endoplasmic reticulum. Ribosomes, mitochondria and numerous granules of different size and density related to a well-developed Golgi apparatus were also found. Mature plasma cells were characterized by the numerous dilated cisternae of rough endoplasmic reticulum filled by a granular material. A small Golgi apparatus and sparse mitochondria were also seen.

\section{Scanning Electron Microscopy}

The irregularly shaped reticular cells showed large, branched cell processes joined to those of the neighbouring cells to form an extensive network (Fig. 6). The cell body and cell processes had a rugged surface with many depressions (Figs. 6, 7).

Macrophage-type reticulum cells were large and oval or rounded, and provided with long processes involved in the extensive reticular network. The nearly smooth cell surface showed randomly distributed weak depressions (Fig. 8).

Monocyte-macrophages and macrophages were the largest interstitial cell types $(8-10 \mu \mathrm{m}$ in diameter). The ruffled cell surface showed numerous folds or finger-like processes (Fig. 9).

Small groups of lymphoid cells $(2.5 \mu \mathrm{m}$ in diameter) were found (Fig. 10a). Some of them showed a rugged cell surface (Fig. 10b).

\section{DISCUSSION}

The results of the few studies carried out on the teleost head-kidney suggest that its morphofunctional features differ from one fish species to another (SMITH et al., 1970; ZAPATA, 1979, 1981; FÄNGE and Nilsson, 1985; Bayne, 1986; ZuASTI and FERrer, 1989). The sea bass head-kidney presents structural features analogous to those of mammalian bone marrow, in agreement with those suggested for some fish species (JORDAN, 1938; ZAPATA, 1979), and in contrast to the lymphopoietic head-kidney present in others (Smith et al., 1967, 1970; ZAPATA, 1979, 1981). The sea bass head-kidney consists of myeloid (Esteban et al., 1989; Meseguer et al., 1990) and scarce lymphoid cells. No lymphopoietic islets are present, the scanty lymphoid cells being isolated or in small clusters. These cells, along with macrophages and melano-macrophages, are densely packed in an extensive network of stromal cells.

\section{Stromal cells}

Only a few references to fish haemopoietic stroma can be found in the literature (KANESADA, 1956; SMith et al., 1970; ZAPATA, 1983; FÄNGE and NiLSSON, 1985) and neither ultrastructural nor functional studies are available. It is generally agreed that the stromal cell types in mammalian bone marrow include endothelial cells, reticular cells, and macrophages (AlLEN and DEXTER, 1982, 1984; CROCKER et al., 1988). The stromal network of sea bass headkidney consists of sinusoids, reticular cells related to 
reticular fibres, and macrophages. This haemopoietic stroma coincides with the basic pattern of mammal haemopoietic stroma, especially as is present in bone marrow (WESTEN and BAINTON, 1979; BAINTON, 1985; CROCKER et al., 1988).

The sinus wall acts, therefore, as the barrier between the haemopoietic site and blood, and consists of endothelial and adventitial cells. A basement membrane may be present or absent. The ultrastructural features of the sea bass head-kidney sinusoidal endothelium suggest an active process of transcytosis associated with a high permeability to water and solutes. Adventitial cells show an ultrastructure closely resembling reticular cells. Their processes, which are connected to one another by desmosomes, may establish close apposition with the neighboring endothelial cells.

Vertebrate reticular cells form a network which physically supports the haemopoietic cells and influences their differentiation (DEXTER, 1982). Histochemical studies have demonstrated that two types of "reticulum cell" can be distinguished in rodent and human bone marrow: a fibroblast-like reticular cell and macrophage-type reticulum cell (BAINTON, 1985). In the sea bass head-kidney we have identified two cell types of differing ultrastructure that presumably correspond to those present in mammals; the same nomenclature has therefore been used. Fibroblast-like reticular cells in the sea bass head-kidney show ultrastructural features of mechanical supportive cells. They probably maintain the framework of reticular fibres. As regard the presence of large filament bundles, both sea bass fibroblast-like reticular cells and adventitial cells may have contractile properties responding to space requirements of the stroma network and also aid the interaction between reticular and haemopoietic cells as it occurs in mammalian bone marrow (DEXTER, 1982; OWEN, 1988). These cells may also contribute decisively to the haemopoietic microenvironment. They have large, round vesicles similar to lipid droplets and, as suggested for other vertebrates (QUESADA et al., 1985), could have the same microenvironmental significance as adipocytes, which seem to be fundamental in haemopoietic proliferation and differentiation (Allen and Dexter, 1976; SORRELl and Weiss, 1980; Allen, 1981).

Macrophage-type reticulum cells of mammalian bone marrow constitute a resident population that is quite different from the immature members of the monocytic series and tissue macrophages (CROCKER et al., 1988). The existence of fish reticular cells with phagocytic ability has previously been indicated (Smith et al., 1970; ZAPATA, 1983). In the sea bass head-kidney we have identified macrophage-type reticulum cells that, like those of mammals (Hum PHREY and SUNDARAM, 1985), are stellate and in close association with surrounding haemopoietic cells. They have phagocytic vesicles and frequently show engulfed haemopoietic cells at different involutive stages. Several authors have proposed that this macrophage population may play a dual role in erythroid homoeostasis by removing damaged cells and cellular debris and by providing a suitable trophic microenvironment for the proliferation and differentiation of haemopoietic cells (CROCKER and GORDON, 1985; CROCKER et al., 1988).

\section{Macrophages}

The head-kidney seems to be the main source of fish macrophages (BRAUN-NESJE et al., 1981). Unlike other vertebrates, fish macrophages have been described in both haematogenous and histogenous forms (JAKOWSKA, 1956; LESTER and DANIELS, 1976). According to the localization (ELLIS, 1976), ultrastructural features (Hightower et al., 1984) or differing glass adherent properties (BRAUN-NESJE et al., 1982), several types of macrophages have been recognized in the same teleost species. Ultrastructurally, monocytes closely resemble heterophilic granulocytes (HiNe et al., 1986) and blast cells (WEINREB and WeINREB, 1969). Macrophages have many of the features seen in monocytes in addition to also having an increased number of primary and secondary lysosomes (Rowley et al., 1988). In the sea bass headkidney we have identified both monocyte-macrophages and macrophages. Sea bass monocyte-macrophages were rare cells, ultrastructurally similar to the monocytes found in other fish (FERGUSON, 1976; KREUTZ. MANN, 1977; BIELEK, 1980; HAWKins et al., 1981; CEnini, 1984).

The sea bass macrophages showed an irregularly outlined nucleus and a heterogeneous cytoplasmic appearance due to the numerous large endocytic vesicles and secondary lysosomes. Fish macrophages operate as the first defence line (ELLIS et al., 1976) and some functional abilities of theirs have recently been reported (BRAUN-NESJE et al., 1982; PETERS and SCHWARZER, 1985). They remove senile or dead cells, as well as antibody-antigen complexes (DAVID, 1970; CORBEL, 1975; INGRAM, 1980). In the sea bass headkidney we have frequently found functionally activated macrophages showing cells debris inside their phagolysosomes.

Extensive literature is available on fish melanomacrophages, these being defined as cells with ultrastructural features similar to those of macrophages 
but containing a considerable amount of pigments (RoBERTS, 1975). Melanin, haemosiderin and lipofuscin may occur within lysosomes or phagosomes (Duve, 1959; STRAuS, 1959) and/or freely in the cytoplasm (AGIUS and AGBEDE, 1984). Melano-macrophages of the sea bass head-kidney usually show abundant melanin granules as in other fish (AGIUS, 1980), and sometimes haemosiderin. In some other teleosts the head-kidney lacks haemosiderin, which is, on the other hand, abundant in the spleen (AGIUS and AGBEDE, 1984). We have never observed lipofuscin granules in our materials. Melanin granules and haemosiderin can be found together inside the lysosomes. Incidentally, the origin and development of melanin-containing cells is poorly understood (AGIUS and AGBEDE, 1984). Although tissue catabolism seems to be the main process for forming pigments within melano-macrophages (AGIUS and AGBEDE, 1984; ZuASTI et al., 1989), it is still a matter of debate as to whether they are melanogenic or melanin-phagocytic cells. Further histochemical and morphofunctional data are required to understand the association of melano-macrophages and lymphoid or haemopoietic tissues, as well as the possible phagocytic defensive role of these cells. Some of these questions are being addressed in present studies.

\section{Lymphocytes and plasma cells}

Functional heterogeneity in fish lymphocytes has been suggested by different methods, such as mitogenicity response (CuChens and Clem, 1977; ChilmonczyK, 1978; Clem et al., 1984; SizEMORE et al., 1984; Miller et al., 1985), but the presence of different lymphoid cell populations and the existence of $\mathrm{T}$ and $\mathrm{B}$ cell analogues have not been convincingly demonstrated. Using morphological criteria, fish lymphoid cells have, at present, been subdivided into lymphoblasts, lymphocytes and plasma cells (ROMESTAND and TRILlES, 1984; ROWLEY et al., 1988), lymphoblasts, prolymphoblasts, prolymphocytes and lymphocytes (MulcaHy et al., 1983) or into mature and immature lymphocytes (Weinberg et al., 1972; SAVAGE, 1983; ZUASTI and FERRER, 1989).

Fish lymphocytes have also been usually classified into large and small cells (TomONAGA et al., 1973; LEWIS et al., 1978; BARBER et al., 1981; SAVAGE, 1983; Temkin and McMillan, 1986). These may be two different functional stages of the same cell type (ELLIS, 1977), or two separate cell populations with different functional properties (PARROT and DESOUSA, 1971). Nevertheless, large and small lymphocytes have not been distinguished in some teleost species, with only a large lymphocyte type being recorded
(Williams and WARNER, 1976; ElARIFI, 1982; RouBAL, 1986). In the sea bass head-kidney we have identified both small and large lymphocytes according to the results of a light microscopical study previously carried out (ROMESTAND and TRILlES, 1984). Small lymphocytes have been described as the easier cell type to identify in the haemopoietic tissue (Williams and WARNER, 1976) but they could be confused with thrombocytes (Rowley et al., 1988). Both lymphocytes and thrombocytes can be unequivocally identified by their ultrastructural features (BIELEK, 1979; DAIMON et al., 1979; EsteBAN et al., 1989). The fine structure of sea bass small lymphocytes is quite similar to that in some teleosts (WEINREB, 1963; FERGUSON, 1976; Ellis, 1977; DOGGETT and HARRIS, 1989). They are agranular cells like those of some fish species (WEINBERG et al., 1972; FERGUSON, 1976; Hightower et al., 1984; ZUASTI and FERRER, 1989). Granular lymphocytes have been described in Ictalurus punctatus, Cyprinus carpio and Carassius auratus (CANnon et al., 1980; Temkin and McMillan, 1986; BIELEK, 1988). The scarce, large mitochondria characteristic of some teleost lymphocytes (FERGUSON, 1976; CANNON et al., 1980) are also present in sea bass. We have not found glycogen as in the lymphocytes of Pleuronectes platessa (Ellis, 1976). Sea bass large lymphocytes show ultrastructural features similar to the lymphoblasts and prolymphocytes described in Esox lucius (MULCAHY et al., 1983) and they are rather similar to proerythroblasts and myeloblasts previously described by us in the sea bass headkidney (EsTEBAN et al., 1989; Meseguer et al., 1990), although they lack the peripheral band of microtubules which characterizes the proerythroblasts. Furthermore, large lymphocytes are always close to the small lymphocytes. Considering the scanty presumptive blast cells in the sea bass head-kidney, the cells identified as proerythroblasts, myeloblasts and some large lymphocytes might correspond to limited potential stem cells.

The origin of the head-kidney lymphocytes is still unresolved. Although thymocyte migration to the head-kidney has been demonstrated during teleost development (TATNER, 1985), the thymic origin of the head-kidney lymphocytes has not been confirmed (BLY, 1985). The sea bass head-kidney does not seem to be a significant place of lymphocyte proliferation according to the few large lymphocytes in mitosis and small lymphocytes observed.

The structure and function of teleost head-kidney plasma cells have been poorly studied (CHILLER et al., 1969; SMith et al., 1970). Plasma cells can be abundant (SMith et al., 1970) or scarce (Mulcahy et al., 1983; SAVAGE, 1983) in fish haemopoietic tissues. This 
cell type was not always recognised in the blood (Ellis, 1977), it being absent (ROMESTAND and TRILLES, 1984) or in very small numbers (BARBER et al., 1981) in some fish. The few circulating plasma cells reflect their limited release from lymphoid or lymphomieloid tissues (ROWLEY et al., 1988). In the sea bass head-kidney we have identified a few mature plasma cells showing dilated cisternae of rough endoplasmic reticulum, similar to those described in other fish (PULSFORD et al., 1982; SAVAGE, 1983; ZuASTI and FERRER, 1989). Developing plasma cells containing some cytoplasmic dense granules, which were absent in sea bass mature plasma cells, are similar to the young plasmocyte or plasmoblast reported in Cyprinus carpio (Temkin and McMillan, 1986).

\section{REFERENCES}

Agrus, C.: Phylogenetic development of melano-macrophage centres in fish. J. Zool. Lond. 191: 11-31 (1980).

Agrus, C. and S. A. Agbede: An electron microscopical study on the genesis of lipofuscin, melanin and haemosiderin in the haemopoietic tissues of fish. J. Fish Biol. 24: 471-488 (1984).

Allen, T. D.: Haemopoietic microenvironments in vitro: ultrastructural aspects. In: Ciba Foundation Symposium 84: Microenvironments in haemopoietic and lymphoid differentiation. Pitman, London, 1981 (p. 38-67).

Allen, T. D. and T. M. Dexter: Cellular interrelationships during in vitro granulopoiesis. Differentiation 6 : 191-194 (1976).

poietic differentiation in long-term bone marrow ture. Differentiation 21: 86-94 (1982).

- : The essential cells of the hemopoietic microenvironment. Exp. Hematol. 12: 517-521 (1984).

Bainton, D. F.: Bone marrow stromal cells, fibroblasts and macrophages. In: (ed. by) R. VAN FurTh: Mononuclear phagocytes. Characteristics, Physiology and function. Martinus Nijhoff, Dordretch, 1985 (p. 125-136).

Barber, D. L., J. E. M. Westermann and M. G. White: The blood cells of the Antarctic icefish Chaenocephalus aceratus Lömberg: light and electron microscopic observations. J. Fish Biol. 19: 11-28 (1981).

Bayne, C. J.: Pronephric leucocytes of Cyprinus carpio: isolation, separation and characterization. Vet. Immunol. Immunopathol 12: 141-151 (1986).

BIELEK, E.: Electron microscopical studies on blood cells of teleosts. III. Granulocytes. Zool. Jahrb. Anat. 103: 105-121 (1979).

- Elektronenmikroskopische Untersuchungen der Blutzellen der Teleostier. IV. Monocyten und Makrophagen. Zool. Jahrb. Anat. 103: 498-509 (1980).

-: Developmental stages and localization of peroxidatic activity in the leukocytes of three teleost species (Cyprinus carpio L., Tinca tinca L., Salmo gairdneri Richardson). Cell Tiss. Res. 220: 163-180 (1981).

: Ultrastructural analysis of leucocyte interaction with tumour targets in a teleost, Cyprinus carpio L. Devel. Comp. Immunol. 12: 809-821 (1988).

BLY, J. E.: The ontogeny of the immune system in the viviparus teleost Zoarces viviparus L. In: (ed. by) M. J. Manning and M. F. Tatner: Fish immunology. Academic Press, London, 1985 (p. 327-341).

Braun-Nesje, R., K. Bertheussen, G. Kaplan and R. SELJELID: Salmonid macrophages: separation, "in vitro" culture and characterization. J. Fish Dis. 4: 141-151 (1981).

Braun-Nesje, R., G. Kaplan and R. Seljelid: Rainbow trout macrophages in vitro: morphology and phagocytic activity. Devel. Comp. Immunol. 6: 281-291 (1982).

Cannon, M. S., H. H. Mollenhauer, T. E. Eurell, D. H. Lewis, A. M. Cannon and C. Tompkins: An ultrastructural study of the leukocytes of the channel catfish, Ictalurus punctatus. J. Morphol. 164: 1-23 (1980).

Cenini, P.: The ultrastructure of leucocytes in carp (Cyprinus carpio). J. Zool. (Lond.) 204: 509-520 (1984).

Chiller, J. M., H. O. Hodgins, V. C. Chambers and R. S. WEISER: Antibody response in rainbow trout (Salmo gairdneri). I. Immunocompetent cells in the spleen and anterior kidney. J. Immunol. 102: 1193-1201 (1969).

ChILmonczyk, S.: In vitro stimulation by mitogens of peripheral blood lymphocytes from rainbow trout (Salmo gairdneri). Ann. Immunol. 129: 3-12 (1978).

Clem, L. W., E. Faulmann, N. W. Miller, C. Elsaes SER, C. J. LoB and M. A. Cuchens: Temperaturemediated processes in teleost immunity: differential effects of in vitro temperatures on mitogenic responses of channel catfish lymphocytes. Devel. Comp. Immunol. 8: 313-322 (1984).

Corbel, M. J.: The immune response in fish: a review. J. Fish Biol. 7: 539-563 (1975).

Crocker, P. R. and S. Gordon: Isolation and characterization of resident stromal macrophages and hematopoietic cell clusters from mouse bone marrow. J. Exp. Med. 162: 993-1014 (1985).

Crocker, P. R., L. Morris and S. Gordon: Novel cell surface adhesion receptors involved in interactions between stromal macrophages and haemopoietic cells. J. Cell Sci. Suppl. 9: 185-206 (1988).

Cuchens, M. A. and L. W. Clem: Phylogeny of lymphocyte heterogeneity. II. Differential effects of temperature on fish T-like and B-like cells. Cell Immunol. 34: 219-230 (1977).

Daimon, T., V. Mizuhira, I. Takahashi and K. UChida: The surface connected canalicular system of carp (Cyprinus carpio) thrombocytes: its fine structure and three dimensional architecture. Cell Tiss. Res. 203: 355365 (1979).

DAvid, H.: Zellschädigung und Dysfunktion. Protoplasmatologia X: 1-612 (1970).

DEXTER, T. M.: Stromal cell associated haemopoiesis. J. Cell. Physiol. Suppl. 1: 87-94 (1982). 
DogGeTt, T. A. and J. E. HARRIS: Ultrastructure of the peripheral blood leucocytes of Oreochromis mossam. bicus. J. Fish Biol. 33: 747-756 (1989).

Duve, C.: Lysosomes. A new group of cytoplasmic particles. In: (ed. by) T. HAYASHI: Subcellular particles. Ronald Press, New York, 1959 (p. 128).

Elarifi, A. E.: The histopathology of larval anisakid nematode infections in the liver of whiting, Merlangius merlangus (L.), with some observations on blood leucocytes of the fish. J. Fish Dis. 5: 411-419 (1982).

EluIS, A. E.: Leucocytes and related cells in the plaice, Pleuronectes platessa. J. Fish Biol. 8: 143-156 (1976).

- The leucocytes of fish: A review. J. Fish Biol. 11: 453-491 (1977).

Ellis, A. E., A. L. S. Munroe and J. J. Roberts: Defense mechanisms in fish. I. A study of the phagocytic system and the fate of intraperitoneally injected particulate material in the plaice (Pleuronectes platessa L.). J. Fish Biol. 8: 67-78 (1976).

Esteban, M. A., J. Meseguer, A. Garcia Ayala and B. Agulleiro: Erythropoiesis and thrombopoiesis in the head-kidney of the sea bass (Dicentrarchus labrax L.). An ultrastructural study. Arch. Histol. Cytol. 52: 407419 (1989).

Fänge, R.: A comparative study of lymphomieloid tissue in fish. Devel. Comp. Immunol. 2: 23-33 (1982).

FäNGE, R. and S. Nilsson: The fish spleen: structure and function. Experientia 41: 152-158 (1985).

Ferguson, H. W.: The ultrastructure of plaice (Pleuronectes platessa) leucocytes. J. Fish Biol. 8: 139-142 (1976).

Hawkins, W. E., M. A. Solangi and R. M. Overstreet: Ultrastructural effects of the coccidium, Eimeria funduli Duszynski, Solangi and Overstreet, 1979, on the liver of killifishes. J. Fish Dis. 4: 281-295 (1981).

Hightower, J. A., L. J. MCCUMBer, M. G. WeLSh, D. S. Whatley, R. E. HartvigSen and M. M. Sigel: Blood cells of Fundulus heteroclitus (L.). J. Fish Biol. 24: 587598 (1984).

Hine, P. M., J. M. Wain, N. C. Boustead and D. M. DUNLOP: Light and electron microscope studies on the enzyme cytochemistry of leucocytes of eels, Anguilla species. J. Fish Biol. 29: 721-736 (1986).

Hume, D. A., J. F. Loutit and S. Gordon: The mononuclear phagocyte system of the mouse defined by immunohistochemical localization of antigen F4/80. Macrophages of bone and associated connective tissue. J. Cell Sci. 66: 189-194 (1984).

Humphrey, J. H. and V. Sundaram: Origin and turnover of follicular dendritic cells and marginal zone macrophages in the mouse spleen. Adv. Exp. Med. Biol. 186: 167-170 (1985).

INGRAM, G. A.: Substances involved in the natural resistance of fish to infection: A review. J. Fish Biol. 16: 2360 (1980).

JaKowska, S.: Morphologie et nomenclature des cellules du sang des téleostéens. Rev. Hematol. II: 519-539 (1956).

Jordan, H. E.: Comparative hematology. In: (ed. by) H.
DOWNEY: Handbook of hematology, 1938 (p. 715-721).

KANESADA, A.: A phylogenetical survey of hemocytopoietic tissues in submammalian vertebrates. With special reference to the differentiation of the lymphocyte and lymphoid tissue. Bull. Yamaguchi Med. School 4: 123 (1956).

KreutzmanN, H. L.: Untersuchungen zur Morphologie des Bluts vom europäischen Aal (Anguilla anguilla). III. Beobachtungen an monozytären und lymphatischen Zellen. Fol. Hematol. 104: 538-557 (1977).

Lester, R. J. G. and B. A. Daniels: The eosinophilic cell of the white sucker, Catostomus commersoni. J. Fish Res. Board. Can. 33: 139-144 (1976).

Lewis, D. H., T. E. Eurell, M. S. Cannon and L. C. GRU MbLES: T and B cell analogues from peripheral blood of immune channel catfish, Ictalurus punctatus. J. Fish Biol. 14: 31-37 (1978).

Meseguer, J., M. A. Esteban, A. Garcia Ayala, A. Lopez Ruiz and B. Agulleiro: Granulopoiesis in the head-kidney of the sea bass (Dicentrarchus labrax L.): An ultrastructural study. Arch. Histol. Cytol. 53: 287296 (1990).

Miller, N. W., R. C. Sizemore and L. W. Clem: Phylogeny of lymphocyte heterogeneity: the cellular requirements for in vitro antibody responses of channel catfish leukocytes. J. Immunol. 134: 2884-2888 (1985).

Mulcahy, M. F., A. G. Savage and N. Casey: The leukocytes of the pike Esox lucius L. Advances in fish biology in Ireland. Irish Fish. Invest. (A): 24 (1983).

Owen, M.: Marrow stromal stem cells. J. Cell Sci. Suppl. 10: 63-76 (1988).

Parrott, D. M. V. and M. B. A. De Sousa: Thymusdependent and thymus-independent populations. Origins, migratory patterns and lifespan. Clin. Exp. Immunol. 8: 663-684 (1971).

Peters, G. and R. Schwarzer: Changes in hemopoietic tissue of rainbow trout under influence of stress. Dis. Aquat. Org. 1: 1-10 (1985).

Pulsford, A., R. Fänge and W. J. W. Morrow: Cell types and interactions in the spleen of the dogfish Scyliorhinus canicula L.: An electron microscopic study. J. Fish Biol. 17: 649-662 (1982).

Quesada, J., B. Agulleiro and M. T. Lozano: Ultrastructure of the granulopoietic microenvironment in the tunica propia of the bursa of Fabricius of white leghorn chicken embryo. J. Submicrosc. Cytol. 17: 537-540 (1985).

RoberTs, R. J.: Melanin-containing cells of the teleost fish and their relation to disease. In: (ed. by) W. E. RiBELIN and G. MIGAKI: The pathology of fishes. University of Wisconsy Press, Medison, Wisconsin, 1975 (p. 399428).

Romestand, B. and J. P. Trilles: Nomenclature et cytologie descriptive des éléments figurés du sang et des organes hémopoiétiques du Bar (Dicentrarchus labrax). Rec. Med. Vet. 160: 833-840 (1984).

Roubal, F. R.: Blood and other possible inflammatory cells in the sparid Acanthopagrus australis (Güenther) $\mathrm{J}$. Fish Biol. 28: 573-594 (1986).

Rowley, A. F., T. C. Hunt, M. Page and G. Mainwar - 
ING: Fish. In: (ed. by) A. F. Rowley and N. A. RAtClif. FE: Vertebrate blood cells. Cambridge University Press, Cambridge, 1988 (p. 19-127).

Savage, A. G.: The ultrastructure of the blood cells of the pike Esox lucius L. J. Morphol. 178: 187-206 (1983).

Sizemore, R. C., N. W. Miller, M. A. Cuchens, C. J. LoBB and L. W. Clem: Phylogeny of lymphocyte heterogeneity: the cellular requiriments for in vitro mitogenic responses of channel catfish leukocytes. J. Immunol. 133: 2920-2924 (1984).

Smith, M., M. Potter and B. Merchant: Antibodyforming cells in the pronephros of the teleost Lepomis machrochirus. J. Immunol. 99: 876-882 (1967).

Smith, A. M., N. A. Wivel and M. Potter: Plasmacytopoiesis in the pronephros of the carp (Cyprinus carpio L.). Anat. Rec. 167: 351-370 (1970).

SoRRELL, J. M. and L. WeIss: Cell interactions between hematopoietic and stromal cells in the embryonic bone marrow. Anat. Rec. 197: 1-19 (1980).

STraus, W.: Rapid cytochemical identification of phagosomas in various tissues of the rat and their differentiation from mitochondria by the peroxidase method. J. Biophys. Biochem. Cytol. 5: 193 (1959).

TATner, M. F.: The migration of labelled tymocytes to the peripheral lymphoid organs in the rainbow trout, Salmo gairdneri Richardson. Devel. Comp. Immunol. 9: 85-91 (1985).

Temkin, R. J. and D. B. McMillan: Gut-associated lymphoid tissue (GALT) of the goldfish, Carassius auratus. J. Morphol. 190: 9-26 (1986).

Tomonaga, S., T. Hirokane and K. Awaka: Lymphoid cells in the hagfish. Zool. Mag. 82: 133-135 (1973).

Weinberg, S. R., C. D. Siegel and A. S. Gordon: Studies on the peripheral blood cell parameters and morphology of the red paradise fish, Macropodus opercularis. Effect of food deprivation on erythropoiesis. Anat. Rec. 175: 7-14 (1972).

WeinReb, E. L.: Studies on the fine structure of teleost blood cells. I. Peripheral blood cells. Anat. Rec. 147: 219-238 (1963).
WeinReb, E. L. and S. Weinreb: A study of experimentally induced endocytosis in a teleost. I. Light microscopy of peripheral blood cell response. Zool. New York Zool. Soc. 54: 25-34 (1969).

Westen, H. and D. F. BAINTon: Association of alkalinephosphatase-positive reticulum cells in bone marrow with granulocytic precursors. J. Exp. Mod. 150: 919-937 (1979).

Williams, R. W. and M. C. WARNER: Some observations on the stained blood cellular elements of channel catfish, Ictalurus punctatus. J. Fish Biol. 9: 491-497 (1976).

Zapata, A.: Estudio ultraestructural de la mielopoiesis en peces teleósteos. Morfol. Norm. Patol. Sec. A 3: 737 747 (1979).

-: Lymphoid organs of teleost fish. II. Ultrastructure of renal lymphoid tissue of Rutilus rutilus and Gobio gobio. Devel. Comp. Immunol. 5: 685-690 (1981).

. : Phylogeny of the fish immune system. Bull. Inst. Pasteur 81: 165-186 (1983).

Zuasti, A. and C. Ferrer: Haemopoiesis in the headkidney of Sparus auratus. Arch. Histol. Cytol. 52: 249 255 (1989).

Zuasti, A., J. R. Jara, C. Ferrer and F. Solano: Occurrence of melanin granules and melanosynthesis in the kidney of Sparus auratus. Pigment Cell Res. 2: 93-99 (1989).
Prof. J. MEsEguer

Departamento de Biología Celular Facultad de Biología

University of Murcia 30100 Murcia, Spain 